\title{
Evaluation of the Usefulness of the Fermented Thistle (Cirsium japonicum) with Lactobacillus rhamnosus BHN-LAB105 for Antioxidative and Whitening Effects
}

\author{
Ye-Eun Park ${ }^{1}$, Gi-Seok Kwon ${ }^{2}$, Byung-Hyuk Kim ${ }^{1}$, Jung-Bok Lee ${ }^{1^{*}}$ \\ ${ }^{1}$ Institute for Development of Bioindustrial Materials, BHNBIO Co., LTD., Jincheon-gun, Chungcheongbuk-do, Korea \\ ${ }^{2}$ Department of Medicinal Plant Resources, Andong National University, Andong-si, Gyeongsangbuk-do, Korea
}

\author{
"Corresponding author: Jung-Bok Lee, \\ Institute for Development of Bioindustrial \\ Materials, BHNBIO Co., LTD., 52 \\ Sincheogsandan1-ro, Deoksan-myeon, \\ Jincheon-gun, Chungcheongbuk-do 27850, \\ Korea \\ Tel.: +8254822 8972 \\ Fax: +8254822 8973 \\ Email: bio91@bhnbio.com
}

Ye-Eun Park and Gi-Seok Kwon contributed equally to this work.

Received September 5, 2018

Revised December 27, 2018

Accepted January 15, 2019

Published March 30, 2019

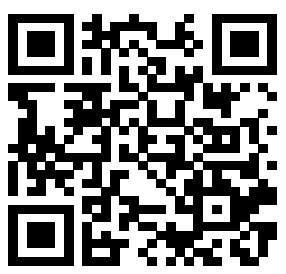

\begin{abstract}
Purpose: This study aimed to increase the effectiveness of the cosmetic functions of fermented thistle (Cirsium japonicum) roots, flowers, and whole plant's extracts with Lactobacillus rhamnosus (L. rhamnosus) BHN-LAB105 and to evaluate the efficacy of the fermented extracts as cosmetic materials. Methods: Samples included methanol extracts of roots, flowers, and whole thistle plant. Total polyphenol and flavonoid contents of each extract were quantified from gallic acid and rutin. The antioxidative effect of the extract was confirmed using a 2, 2-diphenyl-1-picrylhydrazyl (DPPH) radical scavenging assay. Moreover, the whitening effect of each extract was measured using tyrosinase inhibition activity assay in cell-free level. Results: The total polyphenol contents of fermented root and whole thistle extracts were higher (67\%) compared to nonfermented root and whole thistle extracts (32\%). The total flavonoid contents were also higher in all fermented extracts of thistle. The DPPH radical scavenging activity of fermented roots, flowers, and whole thistle extracts was higher by $67 \%, 13 \%$, and $32 \%$ compared to nonfermented extracts, respectively. The tyrosinase inhibition activity was higher by $92 \%, 78 \%$, and $65 \%$ for fermented roots, flower, and whole thistle extracts, respectively. Conclusion: The highest antioxidative and whitening effects were investigated in the fermented whole thistle extracts. As a result, fermented whole thistle extracts with L. rhamnosus BHN-LAB105 could be developed as a potential functional cosmetic material.
\end{abstract}

Keywords: Cirsium japonicum, Antioxidant, Whitening effect, Fermentation, Lactic acid bacteria

\section{Introduction}

엉겅퀴(Cirsium japonicum)는 우리나라 전역에 약 13종이 자 생하는 국화과의 2 년초 식물로서, 데치거나 건조하여 나물 또는 차의 형태로 섭취되고 있다(Chung et al., 2007). 한방에서는 대 계라 불리며 뛰어난 지혈, 항균작용과 해독 작용으로 민간과 한 약처방으로 이용되었다(Mok et al., 2011).

엉겅퀴 뿌리와 꽃은 각각 대계근과 대계화로 불리며, 그 추출 물은 혈뇨, 간염, 고혈압 등에 치료용으로 활용될 뿐만 아니라 항 당뇨 및 항비만 효과가 있다고 보고되었다(Kang et al., 2012). 엉겅퀴 속 식물은 apigenin, luteolin, myricetin 등을 포함하
여 약 78 종의 플라보노이드가 함유되어 있다고 보고되었고, 이들 은 항염증, 항암, 항균 및 면역 증진 등의 활성을 나타낸다고 알 려졌다(Lee et al., 2003; Liu et al., 2006). 플라보노이드는 식 품으로 섭취될 때 심장병 예방에 큰 도움이 되며, 항균제, 항바이 러스제, 항염제, 지질과산화 억제, 항돌연변이성의 효능을 나타 낸다(Das, 1971; Das \& Cheeseman, 1991; Kandaswami \& Middleton, 1994; Middleton \& Kandaswami, 1992; Nonaka et al., 1990). 또한 엉겅퀴는 다른 약용 식물에 비해 약 4 배 많 은 $\mathrm{Fe}$ (철분)를 함유하고 있다(Lee et al., 2001).

엉겅퀴는 예로부터 간장약, 담즙약 등으로 사용되어 왔으며 이 는 엉겅퀴가 함유한 플라보노이드 성분인 실리마린(silymarin) 


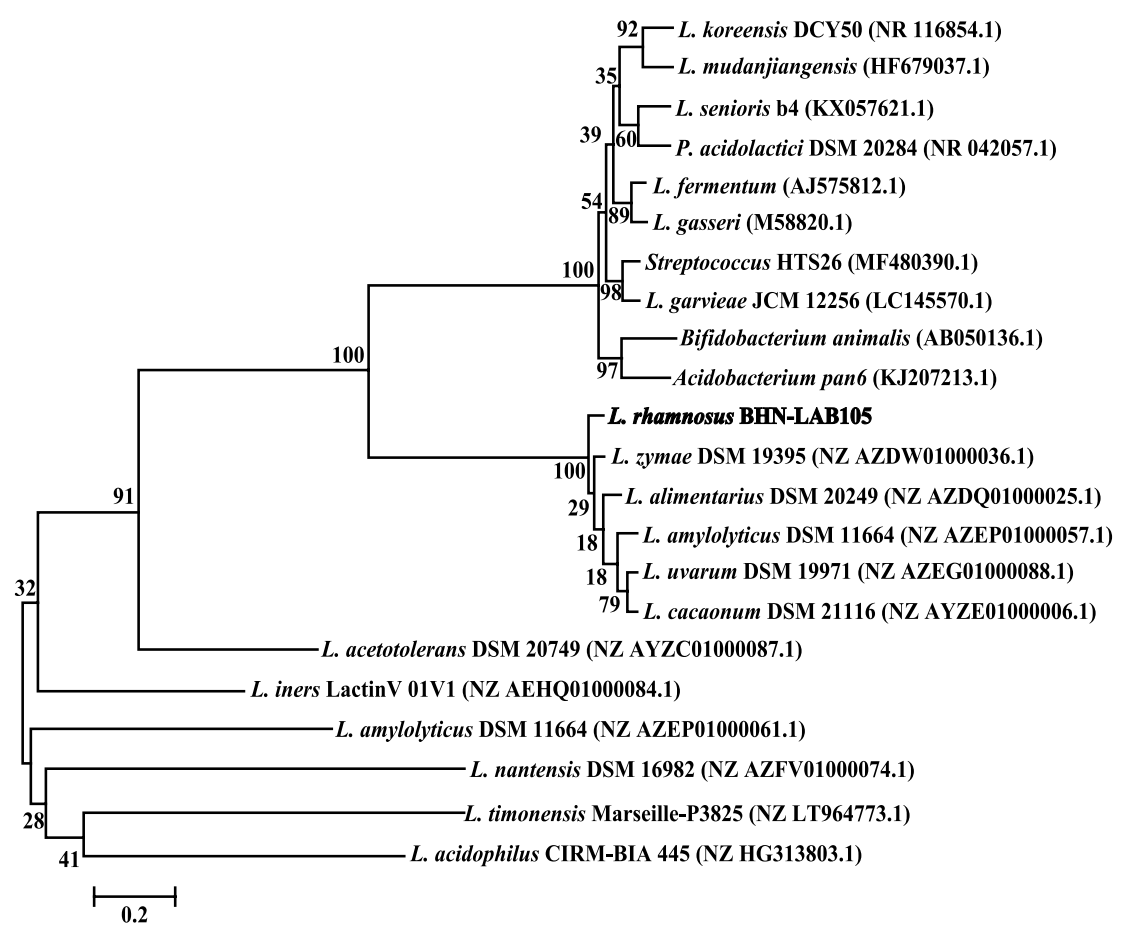

Figure 1. Phylogenetic analysis of BHN-LAB105 and related Lactobacilli based on 165 rRNA gene sequence comparisons.

Lactobacillus rhamnosus BHN-LAB105 was isolated from Kimchi, used for the fermentation of Cirsium japonicum. The strain was identified by the paper disc method with approximately 200 strains. The sequences of isolated strains were compared with the sequences available from the GenBank database. L. rhamnosus, Lactobacillus rhamnosus.

때문이다(Lee et al., 1997). 실리마린은 플라보리그난 계열 화 합물을 총칭하는 말로서, 엉겅퀴 추출물에는 silybin, isosilybin, silychristin, silydianin 등 다양한 플라보리그난 화합물이 포함 하고 있어, 이 복합체를 silymarin이라 한다(Lee et al., 1997). 실리마린(Silymarin)은 예로부터 간장장애 보호효과가 있는 것 으로 보고되었다(Hikino et al., 1984; Muriel \& Mourelle, 1990). 또한 항산화에 관여하고, 각질 세포의 분화와 노화를 억 제하여 피부 노화 방지, 피부염증, 피부암 예방, 피부세포를 보 호 및 멜라닌의 생성과 tyrosinase의 발현 억제능이 있는 것 으로 보고되었다(Choo et al., 2009a; Choo et al., 2009b; Mallikarjuna et al., 2004; Singh \& Agarwal, 2002).

한편 유산균은 식품의 발효에 관여하는 주된 미생물로 발효식 품의 대부분이 유산균 발효에 해당한다(Ryu et al., 2015). 유산 균은 정장작용(Ann et al., 2013), 면역증강효과(Jeong et al., 2007), 항암작용(Kato et al., 1994) 등 다양한 생리활성을 가 지고 있는 것으로 알려져 있으며 유산균 발효는 식품의 영양 또 는 기능성 성분을 증대시켜 그 가치를 증가시킨다(Leroy \& De Vuyst, 2004). 유산균 발효를 통하여 천연 추출물 함유 활성 성 분 및 생리활성의 증가를 목적으로 다양한 연구가 활발하게 진행 되고 있다.

이에 따라 본 연구에서는 부위별로 엉겅퀴를 발효하고, 발효
추출물의 항산화 및 미백활성 효과를 비교 분석하여 발효 엉겅퀴 추출물의 피부미백 원료로서 효능을 평가하였다.

\section{Methods}

\section{1. 시료}

본 연구에 사용된 부위별 엉겅퀴는 진도허브(Korea)에서 구입 하였다. 연구에 사용된 엉겅퀴는 2017년 전라남도 진도에서 재 배 및 수확되었으며 직사광선을 받지 않는 실온에 보관하였다. 실리마린은 Sigma-Aldrich (USA)사에서 구입하였으며 최대 용 해도 $(77.36 \mathrm{mg} / \mathrm{mL})$ 를 $100 \%$ 로 설정하고 농도에 맞추어 희석하 여 사용하였다.

\section{2. 엉겅퀴 추출조건}

엉컹퀴 추출물은 엉겅퀴 전초, 뿌리와 꽃으로 나누어 추출 하였으며, 추출방법은 methanol에 3 일간 침지하고 3 회에 걸 쳐 추출을 진행하였다. 추출된 추출물은 filter paper로 여과한 후 Rotary evaporator (N-1100 and N-1000; EYELA Co., Japan)을 이용하여 감압 농축하고 동결 건조하여 실험에 사용하 였다. 


\section{3. 총 폴리페놀 함량의 측정}

총 폴리페놀 함량의 측정은 Folin-Denis (Smeriglio et al., 2016) 방법에 따라 측정하였다. 엉겅퀴 발효 추출물은 1,000 $\mathrm{ppm}$ 농도로 희석하여 실험에 사용하였다. 본 실험은 각 시험 물 질을 $10 \mu \mathrm{L}, 10 \%$ sdium carbonate $\left(\mathrm{Na}_{2} \mathrm{CO}_{3}\right.$, Sigma-Aldrich) $200 \mu \mathrm{L}, 50 \%$ Folin-ciocalteu reagent (Sigma-Aldrich) 10 $\mu \mathrm{L}$ 를 혼합하여 상온에서 $30 \mathrm{~min}$ 반응 후 $760 \mathrm{~nm}$ 에서 흡광도를 측정하였다. Gallic acid (Sigma-Aldrich)를 표준 물질로 사용 하여 얻어진 표준 곡선을 이용하여 총 폴리페놀 함량 $(\mu \mathrm{g}$ gallic acid equivalent/100 g)을 계산하였다.

\section{4. 총 플라보노이드 함량 측정}

총 플라보노이드 함량의 측정은 flavonoid에 알칼리를 작용 시켜 측정하였다(Zhishen et al., 1999). 시험은 각 시험 물질 을 $20 \mu \mathrm{L}$ 와 $70 \%$ ethanol $80 \mu \mathrm{L}, 5 \%$ sodium nitrite $\left(\mathrm{NaNO}_{2}\right.$, Sigma-Aldrich) $6 \mu \mathrm{L}$ 와 혼합하여 $5 \mathrm{~min}$ 상온에서 반응한 후, $10 \%$ aluminum chloride hexahydrate $\left(\mathrm{AlCl}_{3} 6 \mathrm{H}_{2} \mathrm{O}\right.$, SigmaAldrich) $12 \mu \mathrm{L}$ 를 첨가하여 상온에서 $6 \mathrm{~min}$ 반응하였다. 1 $\mathrm{N}$ sodium hydroxide (NaOH, Sigma-Aldrich) $40 \mu \mathrm{L}$ 를 첨 가하고 $11 \mathrm{~min}$ 배양하여 반응을 종료하고 $420 \mathrm{~nm}$ 에서 흡광 도를 측정하였다. Rutin (Sigma-Aldrich)을 표준 물질로 사 용하여 표준 곡선을 작성하여 총 플라보노이드 함량 $(\mu \mathrm{g}$ rutin equivalent/100 g)을 계산하였다.

\section{DPPH radical 소거활성능 측정}

추출물의 DPPH radical 소거 활성능 측정은 Blois (1958) 방 법에 준하여 $\mathrm{DPPH}$ 에 대한 수소 공여 효과로 측정하였다. $\mathrm{DPPH}$ 는 빛을 차단한 상태에서 $99 \%$ ethanol을 이용하여 $2 \mathrm{mM}$ 농도 가 되도록 희석하여 사용하였다. 각 시험 물질 $20 \mu \mathrm{L}$ 에 $\mathrm{DPPH}$ solution $180 \mu \mathrm{L}$ 를 넣고 $37^{\circ} \mathrm{C}$ 에서 $30 \mathrm{~min}$ 반응시켜 $517 \mathrm{~nm}$ 에 서 흡광도를 측정하였다. 전자공여능은 시험 물질을 첨가한 시험 군과 첨가하지 않은 군의 흡광도 차이를 백분율로 나타내었다.

Antioxidant activity $(\%)=[($ Absorbance of sampleAbsorbance of sample blank)/(Absorbance of controlAbsorbance of blank) $] \times 100$

\section{Tyrosinase 저해 활성능 측정}

Tyrosinase 저해 활성능은 L-tyrosine이 기질로 작용하 여 tyrosinase에 의해 L-tyrosine이 L-DOPA로, L-DOPA 가 다시 L-DOPA quinone으로 전환되는 원리(Jeon et al., 2009)를 이용하였으며, Nerya et al. (2003)와 Masamoto et al. (2003)의 방법을 변형하여 cell-free tyrosinase 활 성을 평가하였다. 각 시험 물질 $10 \mu \mathrm{L}$ 에 $2 \mathrm{mM} \mathrm{L}$-tyrosine
(Sigma-Aldrich, USA) $50 \mu \mathrm{L}$ 와 $0.1 \mathrm{M}$ sodium phosphate buffer $\left(\mathrm{pH}\right.$ 6.8) $90 \mu \mathrm{L}$ 을 첨가하여 $37^{\circ} \mathrm{C}$ 에서 $5 \mathrm{~min}$ 전배양 후, mushroom tyrosinase (110 unit/mL, Sigma-Aldrich, $\mathrm{USA}$ )를 $50 \mu \mathrm{L}$ 더하여 $37^{\circ} \mathrm{C}$ 에서 $15 \mathrm{~min}$ 간 반응시켰다. 반응 후 UV-spectrometer (Spark 10M; TECAN, Switzerland)를 이용하여 $405 \mathrm{~nm}$ 에서 흡광도를 측정하였으며, 양성 대조군은 arbutin을 사용하였다. 결과 값은 tyrosinase를 첨가한 시험군 과 첨가하지 않은 시험군의 흡광도 차이를 백분율로 나타내었다.

Tyrosinase inhibition activity $(\%)=100-[($ Absorbance of sample-Absorbance of sample blank)/(Absorbance of control-Absorbance of blank) $] \times 100$

\section{7. 발효 유산균 분리와 선별}

엉겅퀴의 발효를 위해 사용된 유산균은 국내 김치로부터 분리 및 동정한 L. rhamnosus BHN-LAB105를 사용하였다(Figure 1). 이 균주는 본 연구소에서 보유중인 200여종 균주 중 paper disc법을 통해 활성을 확인 후 선별하였다.

\section{8. 미생물 배양과 발효}

유산균은 MRS (Difco Laboratories Inc., USA)에서 배양하 여 실험에 사용하였으며, 엉겅퀴 $20 \mathrm{~g}$, 유산균 배양액을 $80 \mathrm{~mL}$ 접종하여 $37{ }^{\circ} \mathrm{C}$ 에서 3 일간 $(72 \mathrm{~h})$ 발효하였다.

\section{9. 발효 미생물 성장 확인을 위한 $\mathrm{qPCR}$}

L. rhamnosus BHN-LAB105를 접종하고 시간에 따라 시료 를 채취한 후, 시간에 따른 미생물의 성장을 정량적으로 평가하 기 위해 quantitative polymerase chain reaction (qPCR)을 수 행하였다.

각 시료별 미생물의 군집의 크기를 정량적으로 평가하기 위해 qPCR을 수행하였다. 미생물 군집을 정량하기 위해서 Lacto-F (5'-GCA GCA GTA GGG AAT CTT CCA-3')와 Lacto-R (5'GCA TTY CAC CGC TAC ACA TG-3') primer를, Escherichia coli (E. coil) $\mathrm{DH} 5 \alpha$ 의 total DNA를 주형으로 $\mathrm{PCR}$ 을 수행하 여 $350 \mathrm{bp}$ 의 PCR 산물을 얻었다(Castillo et al., 2006). 각 각의 $\mathrm{PCR}$ 산물은 All-in-oneTM vector (Biofact, Korea)에 cloning하였으며, plasmid DNA는 HiGeneTM Plasmid Mini Prep Kit (Biofact, Korea)를 이용하여 추출하였다. 염기서열 분석은 M13-20F primer (All-in-one ${ }^{\mathrm{TM}}$ Vector Systems manual)를 이용하여 분석하였고, BLAST search를 통해 확인 하였다. 염기서열이 확인된 plasmid DNA는 real-time PCR (CFX96 Touch ${ }^{\mathrm{TM}}$ Real-Time PCR Detection System, Bio$\mathrm{Rad}$ )를 이용하여 melting curve 분석 후 정량분석을 위한 표준 유전자(artificial standard clone)로 사용하였다. 
정량 $\mathrm{PCR}$ 을 위해 Real time $\mathrm{PCR}$ 과 $\mathrm{iTaq}^{\mathrm{TM}} \mathrm{SYBR}^{\circledR}$ Green Supermix with ROX (Bio-Rad)를 이용하였다. Lactobacillus $s p$. 16S rRNA gene 정량 $\mathrm{PCR}$ 은 Lacto-F/R를 이용하였고 (Castillo et al., 2006), 반응조건은 $95^{\circ} \mathrm{C}$ 에서 $15 \mathrm{~min}$ 동안 pre-denaturation 시켜, $95^{\circ} \mathrm{C}$ 에서 $30 \mathrm{~s}$ denaturation, $67^{\circ} \mathrm{C}$ 에 서 $30 \mathrm{~s}$ annealing, $72^{\circ} \mathrm{C}$ 에서 $30 \mathrm{~s}$ extension후 fluorescence 를 측정하고 45 cycles을 수행하였다. 그리고 final extension은 $72^{\circ} \mathrm{C}$ 에서 $5 \mathrm{~min}$ 동안 수행하였다. Melting curve 분석은 $65^{\circ} \mathrm{C}$ 부터 $95^{\circ} \mathrm{C}$ 까지 $0.2^{\circ} \mathrm{C}$ 씩 증가시키면서 fluorescence를 측정하였 다(Kim et al., 2017).

정량을 위해서 표준 유전자를 serial dilutions하여 real timePCR을 수행하였으며, DNA 농도는 NanoDrop ND-2000 (Thermo Scientific, USA)을 이용하여 $1 \mathrm{ng} / \mu \mathrm{L}$ 을 분석에 이용 하였다(Gantner et al., 2011; Park et al., 2008; Radjabian et al., 2008).

\section{Silymarin의 분석}

발효 엉겅퀴 추출물의 실리마린 함량 측정은 Radjabian et al. (2008)의 방법을 이용하여 HPLC (Agilent Technology 1260 Infinity II, USA)로 분석하였다. 컬럼은 Agilent Eclips plus $\mathrm{C} 18(150 \times 4.6 \mathrm{~mm}, 5 \mu \mathrm{m})$ 를 사용하였으며, 이동상으로는 methanol-water $(50: 50, \mathrm{v} / \mathrm{v})$ 를 사용하여 등용매 상태로 분석 하였다. 이동상의 유속은 $1 \mathrm{~mL} / \mathrm{min}$ 로 분석하였으며, $\mathrm{DAD}$ 검출 기를 통해 $288 \mathrm{~nm}$ 파장에서 검출하였다.

\section{1. 통계 처리}

본 연구의 모든 실험 결과는 3 회 반복 측정하여 means \pm standard deviation로 나타내었으며, 통계 분석은 SPSS (SPSS INc., Armonk)를 이용하여 각 시험군 간의 유의성을 검증하 였다. 유의성은 $p<0.01, p<0.05$ 수준에서 Duncan's multiple range test에 따라 분석하였다.

\section{Results and Discussion}

\section{1. 총 폴리페놀 및 플라보노이드 함량 측정}

총 폴리페놀과 총 플라보노이드는 과일 및 엽채류에 풍부하게 함유되어 있으며, 식물이 자외선으로부터 스스로를 보호하기 위 해 만들어내는 물질로 항산화, 항균, 세포 재생 등의 역할을 하는 것으로 알려져 있다(Park et al., 2008). 플라보노이드는 폴리페 놀계 화합물 중 하나이며, 페놀성 화합물은 분자 내 하이드록실기 가 주변의 효소 또는 단백질과 결합하며 활성산소종을 제거해 준 다.

엉겅퀴의 발효 전후 총 폴리페놀과 플라보노이드 함량의 변화 를 분석하였다(Table 1). 발효 전 엉겅퀴 뿌리, 꽃 및 전초의 총 폴리페놀 함량은 각각 $60.93,212.40,142.66 \mu \mathrm{g} / 100 \mathrm{~g}$ 으로 확 인되었고, 발효 후에는 $101.86,128.86,188.40 \mu \mathrm{g} / 100 \mathrm{~g}$ 으로 발효 전 총 폴리페놀의 함량보다 증가되는 것을 확인하였으며, 뿌 리와 꽃에서는 $p<0.01$, 전초에서는 $p<0.05$ 수준 내 유의성을 갖 는 것으로 확인되었다. 총 플라보노이드 함량은 발효 전 엉겅퀴 뿌리, 꽃 및 전초에서 $69.77,146.16,199.61 \mu \mathrm{g} / 100 \mathrm{~g}$ 으로 각 각 분석되었고, 발효 후에는 $102,160.05,210.16 \mu \mathrm{g} / 100 \mathrm{~g}$ 으 로 발효 전 총 플라보노이드 함량보다 증가되는 것을 확인하였으 며, 뿌리와 전초에서는 0.05 수준 내 유의성이 확인되었다. 미생 물 발효를 통해 총 폴리페놀 및 총 플라보노이드 함량이 발효 전 시료보다 증가되는 경향을 확인하였다. 총 폴리페놀 함량은 발효 후 엉겅퀴 뿌리에서 약 $67 \%$ 증가되었고, 반면에 엉겅퀴 꽃은 발 효 후 약 $40 \%$ 감소하였다. 엉겅퀴 전초는 발효 후 약 $32 \%$ 증가하 면서 상대적으로 작은 증가량을 확인하였다. 이는 부위별 특성에 따라 유산균 성장에 영향을 미치며, 미생물 성장은 부위별 엉겅퀴

Table 1. Change in total polyphenol and flavonoid contents of thistle (Cirsium japonicum) extracts depending on the fermentation with Lactobacilli.

\begin{tabular}{lcccc}
\hline & \multicolumn{2}{c}{ Total polyphenol contents $(\mu \mathrm{g} / 100 \mathrm{~g})$} & \multicolumn{2}{c}{ Total flavonoid contents $(\mu \mathrm{g} / 100 \mathrm{~g})$} \\
\cline { 2 - 5 } Roots & Before fermentation & After fermentation & Before fermentation & After fermentation \\
Flowers & 60.93 & $101.86^{* *}$ & 69.77 & $102.00^{*}$ \\
Whole & 212.40 & $128.86^{* *}$ & 146.16 & 160.05 \\
\hline
\end{tabular}

Total polyphenol contents $(\mu \mathrm{g} / 100 \mathrm{~g})$ were calculated with gallic acid as standard and flavonoid contents $(\mu \mathrm{g} / 100 \mathrm{~g})$ were calculated with rutin as a standard $\left({ }^{* *} p<0.01,{ }^{*} p<0.05\right)$.

Table 2. The total polyphenol and flavonoid contents by concentration with silymarin as a standard compound

\begin{tabular}{rrr}
\hline & Total polyphenol contents $(\mu \mathrm{g} / 100 \mathrm{~g})$ & Total flavonoid contents $(\mu \mathrm{g} / 100 \mathrm{~g})$ \\
$10 \%$ & 36.958 & 14.333 \\
$25 \%$ & 72.458 & 46.555 \\
$50 \%$ & 131.041 & 68.555 \\
$100 \%$ & 246.250 & 116.0 \\
\hline
\end{tabular}




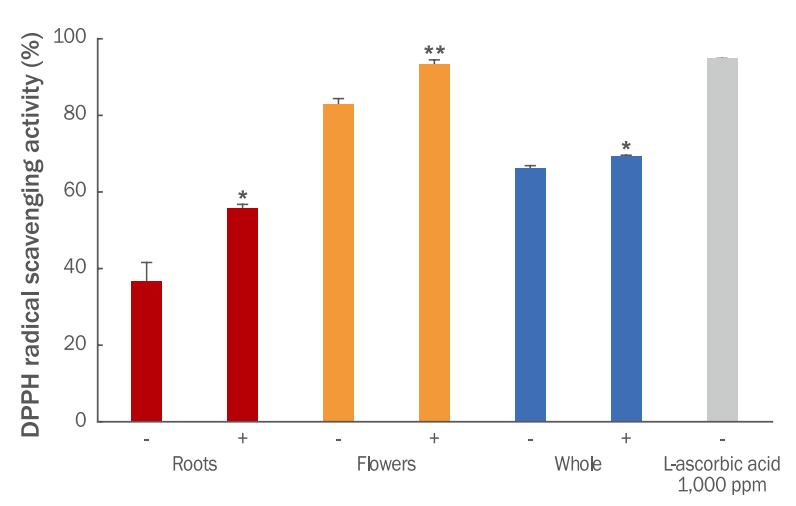

Figure 2. The DPPH radical scavenging activity of fermented roots, flowers, and whole thistle (Cirsium japonicum) extracts with each Lactobacilli.

L-ascorbic acid was used as a positive control, and all test samples were measured at a concentration of 1,000 ppm. DPPH radical scavenging activity was measured at $517 \mathrm{~nm}$. The thistle roots' extract showed a DPPH radical scavenging activity of $36.55 \%$ before fermentation and $55.4 \%$ after fermentation, and thistle flowers' extract showed an activity of $82.7 \%$ before fermentation and $93.08 \%$ after fermentation. Further, the whole thistle extract showed an activity of $65.77 \%$ before fermentation and $69.01 \%$ after fermentation. Consequently the DPPH radical scavenging activity of thistle extracts were increased overall after fermentation. Thus, the overall DPPH radical scavenging activity of thistle extracts increased after fermentation. Percent scavenging of the DPPH free radical was quantified compared to the control $\left(^{* *} p<0.01,{ }^{*} p<0.05\right)$. “-", non-fermented extracts; “+”, fermented extracts; DPPH, 2,2-diphenyl-1-picrylhydrazyl.

의 발효에 영향을 줄 수 있다는 것을 추론할 수 있다(Table 1). 반 면에 총 플라보노이드 함량은 발효 후 엉겅퀴 뿌리, 꽃과 전초에 서 각각 $46 \%, 9 \%, 5 \%$ 증가된 값을 보였다. 플라보노이드는 폴리 페놀류의 일종이지만 결과적으로 플라보노이드 함량의 증감과 폴 리페놀의 증감의 경향이 다른 것은, 플라보노이드 외에 다른 폴리 페놀 성분의 변화가 총 폴리페놀 함량의 증감에 영향을 준 것으로 사료된다(Gwak \& Kim, 2018; Jung \& Ryu, 2018; Lee et al., 2012).

\section{DPPH radical 소거활성능 측정}

엉겅퀴 발효 추출물의 DPPH radical 소거활성능을 측정하였 으며, 양성대조군으로는 L-ascorbic acid를 사용하였으며, 모든 시험 물질은 $1,000 \mathrm{ppm}$ 농도로 측정하였다(Figure 2). 엉겅퀴 뿌리는 발효 전 $36.55 \%$, 발효 후 $55.4 \%$ ( $p<0.05)$ 의 활성을 보 였으며, 엉겅퀴 꽃은 발효 전 $82.7 \%$, 발효 후 $93.08 \%$ ( $p<0.01$ ) 의 활성을 나타내는 것으로 확인되었다. 또한 엉겅퀴 전초는 발 효 전 $65.77 \%$, 발효 후 $68.90 \%$ ( $p<0.05)$ 의 활성을 나타내는 것 으로 확인되어 발효 후 전체적으로 $\mathrm{DPPH}$ 라디칼 소거활성능이 증가되는 것을 확인하였다. 엉겅퀴 뿌리 발효 추출물이 $55.4 \%$

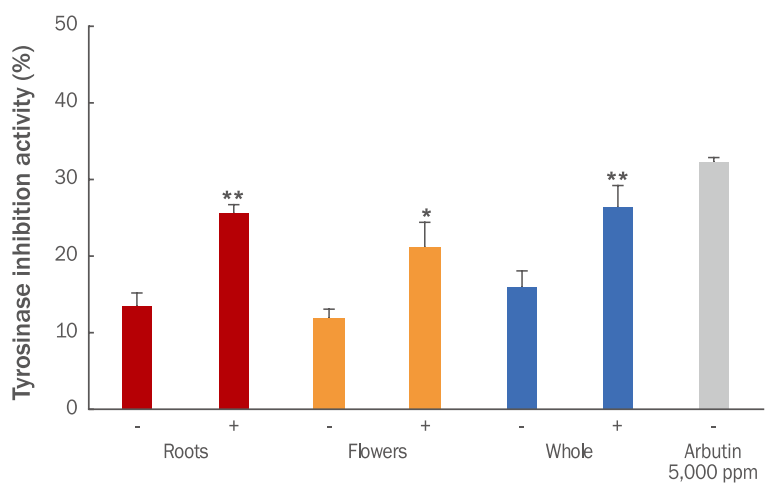

Figure 3. The tyrosinase inhibition activity of fermented roots, flowers, and whole thistle (Cirsium japonicum) extracts with each Lactobacilli.

All test samples were measured at a concentration of 1,000 ppm. Arbutin was used as a positive control at a concentration of $5,000 \mathrm{ppm}$. Tyrosinase inhibition activity was measured at 405 $\mathrm{nm}$. The tyrosinase inhibiton activity of thistle roots' extract was 13.38\% before fermentation and $25.70 \%$ after fermentation and that of thistle flowers' extract was $11.89 \%$ before fermentation and $21.25 \%$ after fermentation. Whole thistle extract showed an activity of $16.03 \%$ before fermentation and $26.52 \%$ after fermentation. Taken together, tyrosinase inhibition activity increased after fermentation. Percent scavenging of the tyrosinase inhibition activity was quantified compared to the control $\left({ }^{* *} p<0.01\right.$, $\left.{ }^{*} p<0.05\right)$. “-, " nonfermented extracts; " +," fermented extracts.

의 활성을 보이며 비발효 추출물(36.5\%)에 비해 약 $52 \%$ 유의적 증가 값을 보였으며, 엉겅퀴 꽃은 발효 추출물(93.08\%)이 비발 효 추출물(82.7\%)에 비해 약 $13 \%$ 증가되었다. 또한 엉겅퀴 전초 는 비발효시 $65.77 \%$ 에서 발효 후 $68.90 \%$ 로 발효하지 않은 전초 $\mathrm{DPPH}$ radical과 비교하여 약 $4 \%$ 수준에서 유의적으로 증가하였 다(Figure 2). L-ascorbic acid는 같은 농도에서 $94.47 \%$ 의 활성 을 보였다(Lee \& Ryu, 2018). L. rhamnosus BHN-LAB 105 은 부위별 엉겅퀴의 발효를 통해 $\mathrm{DPPH}$ radical 소거활성능을 전 체적으로 증가시키는 경향을 확인하였다.

\section{Tyrosinase 저해활성도 측정}

모든 시험물질은 $1,000 \mathrm{ppm}$ 농도에서 tyrosinase 저해 활성도를 측정하였으며, 양성대조군으로 $5,000 \mathrm{ppm}$ 알부틴 (Arbutin, Sigma-Aldrich)을 사용하였다(Figure 3). 엉겅퀴 뿌 리의 tyrosinase 저해활성도는 발효 전 $13.38 \%$, 발효 후 $25.70 \%$ $(p<0.01)$ 로 확인되었으며, 엉겅퀴 꽃은 발효 전 $11.89 \%$, 발효 후 $21.25 \%$ ( $p<0.05)$, 엉겅퀴 전초는 발효 전 $16.03 \%$, 발효 후 $26.52 \%(p<0.01)$ 의 값으로 전체적으로 발효 후 tyrosinase 저 해활성도가 증가되는 것을 확인하였다. 엉겅퀴 발효 추출물의 tyrosinase 저해 활성도는 발효하지 않은 엉겅퀴 추출물에 비해 전반적으로 증가되는 경향을 보였다. 엉겅퀴 뿌리는 약 $92 \%$ 증 

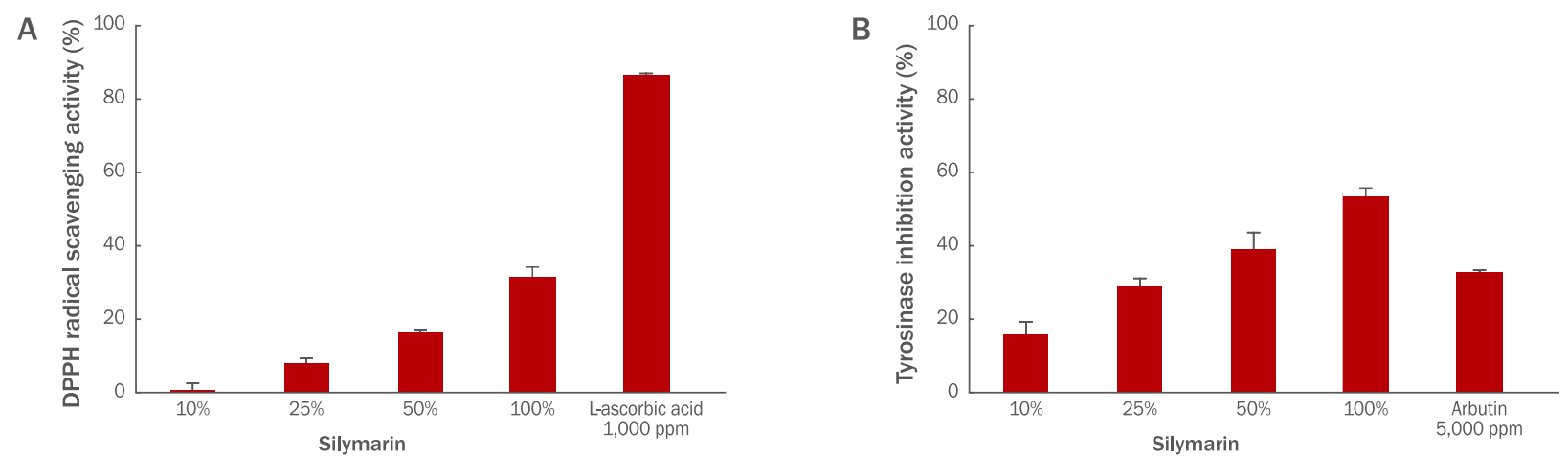

Figure 4. The DPPH radical scavenging activity and tyrosinase inhibition activity of silymarin as a standard compound.

The DPPH radical scavenging activity of silymarin (A) was approximately $31.55 \%$ at $100 \%$ solubility and decreased to $16.39 \%$, $8.01 \%$, and $1.17 \%$, respectively. Conversely, L-ascorbic acid (1,000 ppm) was used as a positive control and showed $87 \%$ activity. The tyrosinase inhibiton activity of silymarin (B) was $15.23 \%$ at $10 \%$ solubility and increased to $28.32 \%, 38.44 \%$, and $53.13 \%$, respectively. 5,000 ppm of arbutin was used as a positive control and showed a tyrosinase inhibitory activity of 32.46\%. DPPH, 2,2-diphenyl-1-picrylhydrazyl.

가율을 보였으며, 엉겅퀴 꽃은 약 $78 \%$ 증가, 엉겅퀴 전초는 약 $65 \%$ 의 유의적 증가를 확인하였다. 시험물질의 농도가 1,000 $\mathrm{ppm}$ 인 것을 감안하면 알부틴 양성대조군(32.47\%)에 비해 높 은 tyrosinase 저해활성도를 나타내는 것으로 판단할 수 있다.

\section{4. 실리마린 standard를 이용한 항산화 및 미백활성도 분석}

엉겅퀴의 유효성분으로 알려진 실리마린의 항산화능과 미백 활성도를 조사하기 위해 총 폴리페놀 함량 및 플라보노이드 함 량, $\mathrm{DPPH}$ radical 소거활성능과 tyrosinase 저해활성도를 측 정하였다(Figure 4, Table 2). 실리마린은 증류수, 실온 상태에 서 $77.36 \mathrm{mg} / \mathrm{L}$ 의 용해도를 갖는다. 본 실험에는 $77.36 \mathrm{mg} /$ $\mathrm{L}$ 를 $100 \%$ 로 설정하고 각각 $50 \%(38.68 \mathrm{mg} / \mathrm{L}), 25 \%(19.34$ $\mathrm{mg} / \mathrm{L}), 10 \%(7.736 \mathrm{mg} / \mathrm{L})$ 로 희석하여 사용하였다. 실리마 린의 총 폴리페놀 및 플라보노이드 함량은 $10 \%$ 용해도 조건에 서 각각 $36.958,14.333 \mu \mathrm{g} / 100 \mathrm{~g}$ 이었으며, $20 \%$ 용해도일 때 $72,458,46.555 \mu \mathrm{g} / 100 \mathrm{~g}, 50 \%$ 용해도일 때 131.041 , $68.555 \mu \mathrm{g} / 100 \mathrm{~g}, 100 \%$ 용해도일 때 246.25, $116.0 \mu \mathrm{g} / 100$ $\mathrm{g}$ 으로 확인되어 농도 증가에 따라 농도의존적으로 증가하였다 (Table 2). DPPH radical 소거활성능(Figure 4A)은 실리마린 $100 \%$ 용해도 조건일 때 약 $31.55 \%$ 의 활성을 보였으며, 농도 감소에 따라 각각 $16.39 \%, 8.01 \%, 0.83 \%$ 의 활성을 보였다. 한편 양성대조군으로 사용된 L-ascorbic acid $1,000 \mathrm{ppm}$ 은 $87 \%$ 의 활성도를 보였다. L-ascorbic acid $1,000 \mathrm{ppm}$ 과 실리 마린을 같은 농도로 가정하여 비교한다면, 실리마린이 약 4.81 배 높은 활성을 나타내는 것으로 추론할 수 있다. 농도별 실리 마린의 tyrosinase 저해활성도 측정결과는 Figure $4 \mathrm{~B}$ 와 같다. 실리마린은 $10 \%$ 용해도 조건에서 $15.23 \%$ 의 활성을 보였으
며 농도 증가에 따라 각각 $28.32 \%, 38.44 \%, 53.13 \%$ 의 활성 을 나타내었다. 양성대조군으로 사용된 arbutin 5,000 ppm은 $32.46 \%$ 의 tyrosinase 저해활성도를 보였다. 기존 발표된 연구 결과에 따르면 실리마린은 유사 농도의 마카 추출물보다 높은 항산화도를 갖으며(Park et al., 2017), 상백피 추출물보다 높 은 tyrosinase 발현 억제능을 갖는 것으로 확인되어 피부미백 소재로서 가능성이 있을 것으로 사료된다(Jee, 2009).

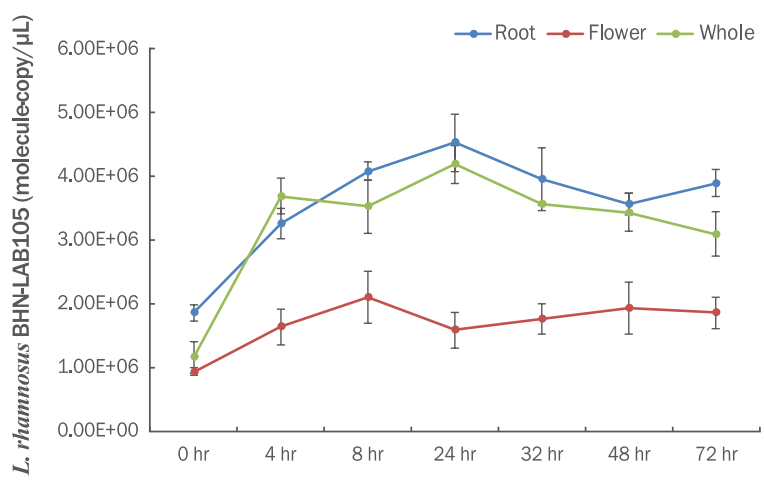

Figure 5. Quantitative analysis of $L$. rhamnosus BHN-LAB105 in the fermentation process of thistle using real-time PCR.

The number of microorganism increased up to $8 \mathrm{~h}$ after the start of fermentation in thistle roots, flowers and whole thistle extracts. After $10 \mathrm{~h}$ of fermentation, it was confirmed that it was maintained as a whole without significant increase or decrease. After $72 \mathrm{~h}$ of fermentation, the number of microorganisms remained constant without the disappearance of the number of Lactobacilli. Thus, fermentation was complete. L. rhamnosus, Lactobacillus rhamnosus; PCR, polymerase chain reaction. 
(A)

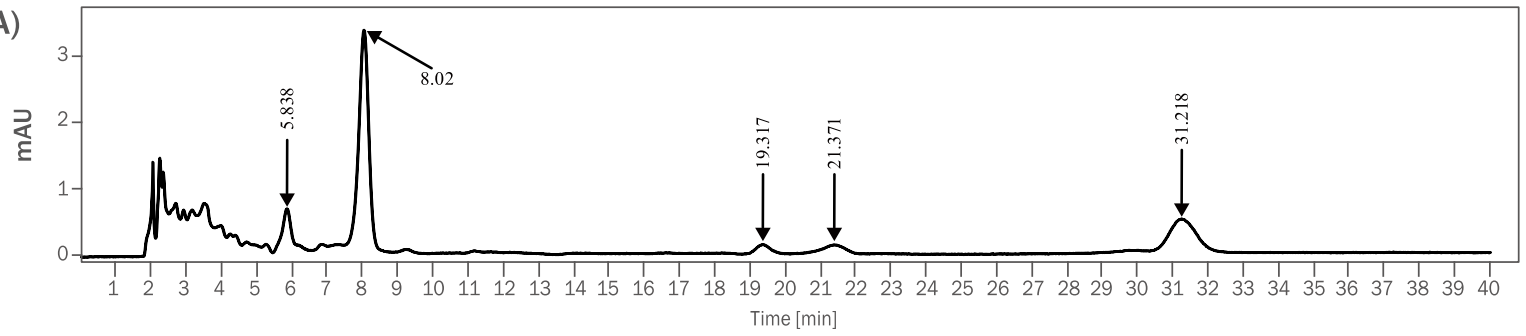

(B)

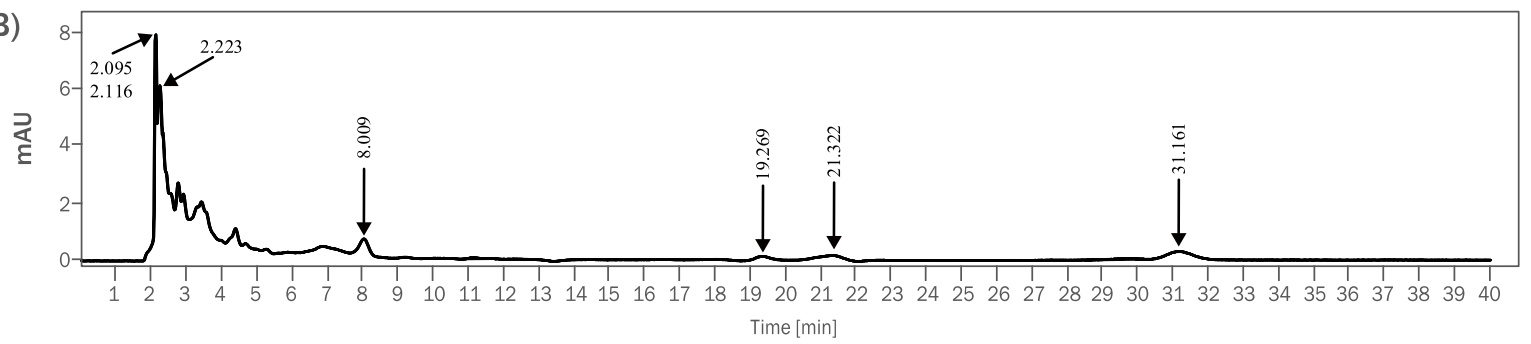

Figure 6. HPLC analysis of the nonfermented and fermented whole thistle extracts.

The whole thistle was analyzed before and after fermentation. The major component peaks of the whole thistle extract before fermentation (A) were detected at 8.02, 19.31, 21.37, and $31.21 \mathrm{~min}$, and various peaks were detected within 10 min of retention time. The main peaks of the whole thistle extract after fermentation (B) were detected at 2.11, 2.22, and 8.00 min. Unlike the whole thistle extract before fermentation, various peaks were observed within $5 \mathrm{~min}$ of retention time. It was deduced that the high molecular weight components were converted into low molecular weight components due to fermentation by Lactobacilli. HPLC, high-performance liquid chromatography.

\section{Real time $\mathrm{PCR}$ 을 이용한 $\mathrm{BHN}-\mathrm{LAB} 105$ 의 정량}

발효 시간에 따른 유전자 copy수를 정량하기 위해 real time-PCR을 수행하였다(Figure 5). 발효 도입 시 엉겅 퀴 뿌리, 꽃과 전초의 발효미생물 copy수는 각각 $1.83 \times 10^{6}$ $\pm 1.27 \times 10^{5}$ molecule•copy $/ \mu \mathrm{L}, 9.03 \times 10^{5} \pm 5.89 \times 10^{4}$ molecule•copy/ $\mu \mathrm{L}, 1.13 \times 10^{6} \pm 2.42 \times 10^{5}$ molecule•copy/ $\mu \mathrm{L}$ 이었으며, $8 \mathrm{~h}$ 후 $4.06 \times 10^{6} \pm 1.41 \times 10^{5}$ molecule•copy/ $\mu \mathrm{L}, 2.07 \times 10^{6} \pm 4.10 \times 10^{5}$ molecule $\bullet$ copy $/ \mu \mathrm{L}, 3.50 \times 10^{6}$ $\pm 4.20 \times 10^{5}$ molecule copy/ $\mu \mathrm{L}$ 로 증가하였다. 또한 엉겅퀴 뿌리, 꽃과 전초에서 발효 $10 \mathrm{~h}$ 이후로는 크게 증가하거나 감 소되는 경향 없이 전체적으로 유지되는 것을 확인하였다. 발 효 시작 $72 \mathrm{~h}$ 후 엉겅퀴 뿌리의 copy수는 $3.87 \times 10^{6} \pm 2.14$ $\times 10^{5}$ molecule•copy/ $\mu \mathrm{L}$ 이었고, 엉겅퀴 꽃은 $1.83 \times 10^{6} \pm$ $2.48 \times 10^{5}$ molecule•copy $/ \mu \mathrm{L}$, 엉겅퀴 전초는 $3.07 \times 10^{6} \pm$ $3.46 \times 10^{5}$ molecule•copy/ $\mu \mathrm{L}$ 로서 유산균의 사멸 없이 유지 되는 것을 확인하였고 이로써 발효를 종결하였다.

\section{6. 엉겅퀴의 발효 추출물 물질분석 (HPLC)}

HPLC를 이용하여 엉겅퀴와 발효에 따른 엉겅퀴 추출물의 성분 변화를 분석하였다(Figure 6). 발효 전과 발효 후의 엉 겅퀴 전초를 분석하였으며, 발효 전 엉겅퀴 전초 추출물의 주 요 성분 피크는 $8.02,19.31,21.37,31.21 \mathrm{~min}$ 에 검출되었
으며 retention time $10 \mathrm{~min}$ 이내에 다양한 피크가 검출되는 것을 확인하였다(Figure $6 \mathrm{~A}$ ). 발효 후 엉겅퀴 전초의 주요 피 크는 $2.11,2.22,8.00 \mathrm{~min}$ 에서 검출되었다(Figure $6 \mathrm{~B}$ ). 발 효 전 엉겅퀴 전초와 다르게 retention time $5 \mathrm{~min}$ 이내에 다 양한 피크가 관찰되며, 이는 높은 분자량의 성분들이 유산균 발효를 통해 전환되어 저분자화 된 것으로 추론된다. 또한, 약 $19,21,31 \mathrm{~min}$ 에 검출되는 피크는 발효 전과 발효 후가 매우 비슷한 값을 갖는 것으로 보아, 해당 성분은 발효에 의해 전환 또는 저분자화 되지 않은 것으로 판단된다. 향후, 미생물에 의 한 엉겅퀴 발효과정에서 생물 전환되는 물질과 미생물의 대사 과정에 관한 연구가 필요할 것으로 사료된다.

또한, 본 연구팀이 분리한 발효미생물인 L. rhamnosus BHN-LAB105는 엉겅퀴 발효과정을 통해 발효 추출물의 항 산화능과 미백효과를 증진시키는 것으로 확인되었으며, 기능 성 화장품에서 요구하는 항산화 및 미백 효과를 증진시킬 수 있는 유용미생물로 활용이 가능한 것을 확인하였다. 또한, 미 생물 발효는 천연물이 가지는 화장품 소재에서 요구하는 항 산화와 미백과 같은 기능성 효과를 증가시킬 수 있는 매우 유 용한 기술이라 할 수 있다(Park et al., 2018; Yoon et al., 2018). 


\section{Conclusion}

실리마린과 엉겅퀴 부위별 발효 추출물의 항산화능을 비교한 결과, 엉겅퀴 꽃, 전초, 뿌리 순서로 실리마린보다 높은 $\mathrm{DPPH}$ 라디칼 소거활성능을 확인하였으며, 발효를 하면 그 값이 더 높게 나타났다. 총 폴리페놀과 플라보노이드 함량은 실리마린 $100 \%$ 조건에서 각각 $246.26,116 \mu \mathrm{g} / 100 \mathrm{~g}$ 으로 확인되었으나 발효하지 않은 엉겅퀴 전초에서는 $142.66 \mathrm{~g} / 100 \mathrm{~g}$ 과 199.61 $\mathrm{g} / 100 \mathrm{~g}$ 로 매우 높은 값을 나타내었고, 미생물 발효 후 엉겅퀴 전초 추출물의 총 폴리페놀 함량은 $188.4 \mu \mathrm{g} / 100 \mathrm{~g}$, 총 플라보 노이드 함량은 $210.16 \mu \mathrm{g} / 100 \mathrm{~g}$ 으로 모두 증가하는 것을 확인 하였다. 미생물을 이용해 발효한 엉겅퀴는 엉겅퀴의 지표물질 로 알려진 실리마린보다 높은 총 폴리페놀과 총 플라보노이드 함량을 가지는 것을 확인하였다. 또한, L. rhamnosus $\mathrm{BHN}-$ LAB105를 활용한 발효를 통해 부위별 발효 엉겅퀴 추출물의 미 백 활성능이 증가되는 확인하였으며, 발효 엉겅퀴 추출물의 미백 활성도는 $1,000 \mathrm{ppm}$ 농도의 발효 엉겅퀴 전초가 $26.53 \%$, 발효 엉겅퀴 뿌리 $25.7 \%$, 발효 엉겅퀴 꽃 $21.26 \%$ 의 값을 보인 반면 실리마린은 $100 \%$ 용해도 조건(77.36 ppm)에서 $53.13 \%$ 로 비교 적 높은 값을 나타내었다. 하지만 순수한 실리마린 물질을 화장 품 소재로 활용하는 것은 산업적 측면에서 매우 어려우며, 순수 한 실리마린 물질을 이용하여 미백 활성도 $53.13 \%$ 이상의 효과 를 기대하는 것 역시 매우 어렵다고 판단된다. 따라서 순수한 실 리마린 물질을 다기능성 화장품 소재로서 산업에 적용하기에는 한계가 있을 것으로 판단되며, 엉겅퀴 발효 추출물이 다기능성 화장품 소재로서 순수한 실리마린 물질보다 활용도가 높을 것으 로 판단된다.

본 연구를 통해 발효 엉겅퀴 전초 추출물은 항산화 및 미백활 성능이 엉겅퀴 뿌리 및 꽃보다 높으며, 추출물의 농도를 제어하 여 항산화능 또는 미백효과를 갖는 화장품용 천연 소재로서의 활 용 가능성이 매우 높다고 판단된다.

\section{Acknowledgements}

이 논문은 2017학년도 안동대학교 연구비에 의하여 연구되었 음.

\section{References}

Ann YG, Jang BC, Park SJ. Biological activity and improvement effect on irritable bowel syndrome of wax gourd extract and probiotic lactic acid bacteria. The Korean Journal of Food And Nutrition, 26: 137-145, 2013.
Blois MS. Antioxidant determinations by the use of a stable free radical. Nature, 181: 1199-1200, 1958.

Castillo M, Martín-Orúe SM, Manzanilla EG, Badiola I, Martín M, Gasa J. Quantification of total bacteria, Enterobacteria and Lactobacilli populations in pig digesta by real-time PCR. Veterinary Microbiology, 114: 165-170, 2006.

Choo SJ, Ryoo IJ, Kim YH, Xu GH, Kim KH, Han CS, Kim SJ, Kim JW, Son ED, Yoo ID. Hypopigmentary effect of milk thistle extract silymarin. Journal of the Society of Cosmetic Scientists of Korea, 35: 151-158, 2009a.

Choo SJ, Ryoo IJ, Kim YH, Xu GH, Kim WG, Kim KH, Moon SJ, Son ED, Bae K, Yoo ID. Silymarin inhibits melanin synthesis in melanocyte cells. The Journal of Pharmacy and Pharmacology, 61: 663-667, 2009b.

Chung MS, Um HJ, Kim CK, Kim GH. Development of functional tea product using Cirsium japonicum. Journal of the Korean Society of Dietary Culture, 22: 261-265, 2007.

Das NP. Studies on flavonoid metabolism: absorption and metabolism of (+)-catechin in man. Biochemical Pharmacology, 20: 3435-3445, 1971.

Das NP, Cheeseman KH. Flavonoids in biology and medicine III current issues in flavonoids research. Free Radical Research Communications, 14: 77-78, 1991.

Gantner S, Andersson AF, Alonso-Sáez L, Bertilsson S. Novel primers for $16 \mathrm{~S}$ rRNA-based archaeal community analyses in environmental samples. Journal of Microbiological Methods, 84: 12-18, 2011.

Gwak JS, Kim CD. Persicaria thunbergii extract as a physiologically active cosmetic ingredient. Asian Journal of Beauty and Cosmetology, 16: 381-392, 2018.

Hikino H, Kiso Y, Wagner H, Fiebig M. Antihepatotoxic actions of flavonolignans from Silybum marianum fruits. Planta Medica, 50: 248-250, 1984.

Jee SO. Antioxidant activities and whitening effect of the Mulberry (Morus alba L.) root Bark extracts. Korean Journal of Plant Resources, 22: 145-151, 2009.

Jeon M, Lee KM, Lim YH, Kim JK. Rhapontigenin production by bioconversion and inhibition of melanin synthesis. Microbiology and Biotechnology Letters, 37: 49-54, 2009.

Jeong SG, Ham JS, Kim HS, Noh YB, Chae HS, Ahn CN, Han GS, Choi SH. Anti-allergy effect of lactic acid bacteria. 
Journal of Korean Dairy Technology and Science Association, 25: 21-25, 2007.

Jung YH, Ryu MJ. Anti-oxidative and anti-inflammatory effects of Codonopsis lanceolata skin extracts. Asian Journal of Beauty and Cosmetology, 16: 347-357, 2018.

Kandaswami C, Middleton E Jr. Free radical scavenging and antioxidant activity of plant flavonoids. Advances in Experimental Medicine and Biology, 366: 351-376, 1994.

Kang HJ, Mok JY, Cho JK, Jeon IH, Kim HS, Park JM, Jeong SI, Shim JS, Jang SI. Protective effects of leaf and flower extracts from Cirsium japonicum var. ussuriense on oxidative damage in normal human erythrocytes and plasma. Korean Journal of Pharmacognosy, 43: 66-71, 2012.

Kato I, Endo K, Yokokura T. Effects of oral administration of Lactobacillus casei on antitumor responses induced by tumor resection in mice. International Journal of Immunopharmacology, 16: 29-36, 1994.

Kim BH, Jang JO, Joa JH, Kim JA, Song SY, Lim CK, Kim CH, Jung YB, Seong KC, Kim HS, Moon DG. A comparison of the microbial diversity in Korean and Chinese postfermented teas. Microbiology and Biotechnology Letters, 45: 71-80, 2017.

Lee BC, Park JO, Ryu BH. Antioxidative effects of silymarin and silybin purified from Silybum marianum on lipid peroxidation. The Korean Journal of Food And Nutrition, 10: 37-43, 1997.

Lee HK, Kim JS, Kim NY, Kim MJ, Park SU, Yu CY. Antioxidant, antimutagenicity and anticancer activities of extracts from Cirsium japonicum var. ussuriense KITAMURA. Korean Journal of Medicinal Crop Science, 11: 53-61, 2003.

Lee JM, Ryu MJ. Efficacy of cosmetic materials using Aronia melanocarpa leaf extracts. Asian Journal of Beauty and Cosmetology, 16: 179-190, 2018.

Lee MY, Yoo MS, Whang YJ, Jin YJ, Hong MH, Pyo YH. Vitamin $\mathrm{C}$, total polyphenol, flavonoid contents and antioxidant capacity of several fruit peels. Korean Journal of Food Science and Technology, 44: 540-544, 2012.

Lee JM, Son ES, Oh SS, Han DS. Contents of total flavonoid and biological activities of edible plants. Journal of The Korean Society of Food Culture, 16: 504-514, 2001.

Leroy F, De Vuyst L. Lactic acid bacteria as functional starter cultures for the food fermentation industry. Trends in Food Science \& Technology, 15: 67-78, 2004.

Liu S, Luo X, Li D, Zhang J, Qiu D, Liu W, She L, Yang Z. Tumor inhibition and improved immunity in mice treated with flavone from Cirsium japonicum DC. International Immunopharmacology, 6: 1387-1393, 2006.

Mallikarjuna G, Dhanalakshmi S, Singh RP, Agarwal C, Agarwal R. Silibinin protects against photocarcinogenesis via modulation of cell cycle regulators, mitogen-activated protein kinases, and Akt signaling. Cancer Research, 64: 6349-6356, 2004.

Masamoto Y, Ando H, Murata Y, Shimoishi Y, Tada M, Takahata K. Mushroom tyrosinase inhibitory activity of esculetin isolated from seeds of Euphorbia lathyris L. Bioscience, Biotechnology, and Biochemistry, 67: 631634, 2003.

Middleton E Jr, Kandaswami C. Effects of flavonoids on immune and inflammatory cell functions. Biochemical Pharmacology, 43: 1167-1179, 1992.

Mok JY, Kang HJ, Cho JK, Jeon IH, Kim HS, Park JM, Jeong SI, Shim JS, Jang SI. Antioxidative and anti-inflammatory effects of extracts from different organs of Cirsium japonicum var. ussuriense. The Korea Journal of Herbology, 26: 39-47, 2011.

Muriel P, Mourelle M. Prevention by silymarin of membrane alterations in acute $\mathrm{CCl} 4$ liver damage. Journal of Applied Toxicology, 10: 275-279, 1990.

Nerya O, Vaya J, Musa R, Izrael S, Ben-Arie R, Tamir S. Glabrene and isoliquiritigenin as tyrosinase inhibitors from licorice roots. Journal of Agricultural and Food Chemistry, 51: 1201-1207, 2003.

Nonaka G, Nishioka I, Nishizawa M, Yamagishi T, Kashiwada Y, Dutschman GE, Bodner AJ, Kilkuskie RE, Cheng YC, Lee $\mathrm{KH}$. Anti-AIDS agents, 2: inhibitory effect of tannins on HIV reverse transcriptase and HIV replication in $\mathrm{H} 9$ lymphocyte cells. Journal of Natural Products, 53: 587595, 1990.

Park SJ, Kim OL, Rha YA. Component analysis and antioxidant activity of Maca. Culinary Science and Hospitality Research, 23: 137-144, 2017.

Park SJ, Kim ES, Choi YS, Kim JD. Effcts of sophorae fructus on antioxidative activities and lipid levels in rats. Journal of the Korean Society of Food Science and Nutrition, 37: 1120-1125, 2008. 
Park YE, Kim BH, Yoon YC, Kim JK, Lee JH, Kwon GS, Hwang HS, Lee JB. Total polyphenol contents, flavonoid contents, and antioxidant activity of roasted-flaxseed extracts based on lactic-acid bacteria fermentation. Journal of Life Science, 28: 547-554, 2018.

Radjabian T, Rezazadeh SH, Fallah Huseini H. Analysis of silymarin components in the seed extracts of some milk thistle ecotypes from Iran by HPLC. Iranian Journal of Science and Technology, 32: 141-146, 2008.

Ryu EH, Yoon HH, Jung JH. Characteristics of lactic acid fermentation of black raspberry juice using the Lactobacillus plantarum GBL17 strain. Korean Journal of Food and Cookery Science, 31: 773-780, 2015.

Singh RP, Agarwal R. Flavonoid antioxidant silymarin and skin cancer. Antioxidants \& Redox Signaling, 4: 655663, 2002.
Smeriglio A, Galati EM, Monforte MT, Lanuzza F, D'Angelo V, Circosta C. Polyphenolic compounds and antioxidant activity of cold-pressed seed oil from finola cultivar of Cannabis sativa L. Phytotherapy Research, 30: 12981307, 2016.

Yoon YC, Kim BH, Kim JK, Lee JH, Park YE, Kwon GS, Hwang HS, Lee JB. Verification of biological activities and tyrosinase inhibition of ethanol extracts from Hemp seed (Cannabis sativa L.) fermented with lactic acid bacteria. Journal of Life Science, 28: 688-696, 2018.

Zhishen J, Mengcheng T, Jianming W. The determination of flavonoid contents in mulberry and their scavenging effects on superoxide radicals. Food Chemistry, 64: 555-559, 1999. 


\section{국문초록}

\section{Lactobacillus rhamnosus BHN-LAB105를 이용한 발효 엉겅퀴의 항산화 및 미백효 과에 대한 유용성 평가}

박예은 ${ }^{1}$, 권기석 ${ }^{2}$, 김병혁 ${ }^{1}$, 이중복 ${ }^{1 *}$

${ }^{1}$ (주)비에이치앤바이오 생물산업소재개발연구소, 충청북도 진천군, 한국

${ }^{2}$ 안동대학교 생약자원학과, 경상북도 안동시, 한국

목적: 본 연구는 Lactobacillus rhamnosus (L. rhamnosus) BHN-LAB105를 이용하여 엉겅퀴의 뿌리, 꽃과 전초를 발효한 발효추 출물의 화장품 소재로서의 효능을 높이고, 화장품 원료로서의 효과를 평가하고자 한다. 방법: 연구에 사용한 엉겅퀴의 뿌리, 꽃, 전 초 발효추출물은 메탄올을 이용하여 추출하였다. 총 폴리페놀과 총 플라보노이드 함량은 gallic acid와 rutin에 의해 각각 정량하였 다. 추출물의 항산화능은 2, 2-diphenyl-1-picrylhydrazyl (DPPH) radical scavenging assay를 통해 확인하였다. 또한, 추출물의 미백효과는 tyrosinase inhibition activity assay를 통해 분석하였다. 결과: 발효를 통한 엉겅퀴 뿌리 및 전초 추출물의 총 폴리페놀 함량은 발효하지 않는 엉겅퀴 추출물에 비해 각각 $67 \%$ 와 $32 \%$ 증가하였다. 또한, 총 플라보노이드는 모든 발효 추출물에서 증가하 는 것을 확인했다. 엉겅퀴 발효 추출물의 DPPH 라디칼 소거능은 발효 후 엉겅퀴 뿌리, 꽃, 전초 추출물에서 각각 $67 \%, 13 \%, 32 \%$ 증가하였다. Tyrosinase 저해 활성은 발효 각 부위에서 각각 $92 \%, 78 \%$ 및 $65 \%$ 증가되는 것으로 분석되었다. 결론: 항산화능과 미 백효과는 발효 엉겅퀴 전초 추출물에서 가장 높게 나오는 것으로 분석되었다. 이로써 L. rhamnosus BHN-LAB105로 발효된 엉겅 퀴 전초 추출물은 기능성 화장품 소재의 후보물질로서 발전 가능할 것으로 판단된다.

핵심어: 엉겅퀴, 항산화, 미백효과, 발효, 유산균

이 논문은 2017학년도 안동대학교 연구비에 의하여 연구되었음.

\section{참고문헌}

강현주, 목지예, 조정근, 전인화, 김현수, 박지민, 정승일, 심재석, 장선일. 엉겅퀴(Cirsium japonicum var. ussuriense)

잎 및 꽃 추출물이 정상인 적혈구와 혈장의 산화적 손상에 대한 보호효과. 생약학회지, 43: 66-71, 2012.

곽정심, 김춘득. 화장품 소재로서 고마리 추출물의 생리활성. 아시안뷰티화장품학회지, 16: 381-392, 2018.

김병혁, 장종옥, 좌재호, 김진아, 송승엽, 임찬규, 김천환, 정영빈, 성기철, 김희식, 문두경. 한국과 중국 미생물 발효차의

미생물 군집분석 및 비교. 한국미생물·생명공학회지, 45: 71-80, 2017.

류은혜, 윤해훈, 정지혜. Lactobacillus plantarum GBL17 균주를 이용한 복분자 유산발효 특성. 한국식품조리과학회지,

31: 773-780, 2015.

목지예, 강현주, 조정근, 전인화, 김현수, 박지민, 정승일, 심재석, 장선일. 엉겅퀴(Cirsium japonicum var. ussuriense)

부위별 추출물의 항산화 및 항염증 효과. 대한본초학회지, 26: 39-47, 2011.

박성진, 김옥란, 나영아. 마카(Lepidium meyenii)의 부위별 함유성분 및 항산화 활성 비교. 한국조리학회지, 23: 137-

144, 2017

박성진, 김은실, 최영수, 김종대. 괴각(Sophorae fructus) 추출물이 흰쥐의 항산화 활성 및 지질농도에 미치는 영향. 한국

식품영양과학회지, $37: 1120-1125,2008$.

박예은, 김병혁, 윤여초, 김중규, 이준형, 권기석, 황학수, 이중복. 유산균 발효에 따른 볶은 아마씨 추출물의 폴리페놀, 플

라보노이드 함량 및 항산화 활성. 생명과학회지, 28: 547-554, 2018.

안용근, 장병철, 박세준. 동아 추출물과 프로바이오틱 유산균의 생리활성 및 과민성대장증후군 개선 효과. 한국식품영양학 
회지, $26: 137-145,2013$.

윤여초, 김병혁, 김중규, 이준형, 박예은, 권기석, 황학수, 이중복. 대마씨 발효 추출물의 생리 활성 및 미백 활성 검증. 생 명과학회지, 28: 688-696, 2018.

이민영, 유미소, 황유정, 진유정, 홍명희, 표영희. 과일 껍질의 비타민C, 폴리페놀, 플라보노이드 함량과 항산화 활성. 한 국식품과학회지, $44: 540-544,2012$.

이백천, 박종옥, 류병호. 엉겅퀴로부터 분리 정제한 Silymarin 및 Silybin의 지질 과산화에 대한 항산화 효과. 한국식품영 양학회지, 10: 37-43, 1997.

이정민, 유민정. 아로니아 잎 추출물을 이용한 화장품 소재 개발. 아시안뷰티화장품학회지, 16: 179-190, 2018.

이종미, 손은심, 오상석, 한대석. 식물성 식품중 총플라보노이드 함량과 생리활성 탐색. 한국식생활문화학회지, 16: 504$514,2001$.

이희경, 김주성, 김나영, 박상언, 김명조, 유창연. 엉겅퀴 추출물의 항산화성, 항돌연변이원성 및 항암활성 효과. 한국약용 작물학회지, 11: 53-61, 2003.

전민, 이강문, 임영희, 김정근. 생물전환에 의한 Rhapontigenin의 생산 및 멜라닌 합성저해. 한국미생물·생명공학회지, 37: 49-54, 2009.

정미숙, 엄혜진, 김재광, 김건희. 플라보노이드 함유 엉겅퀴를 이용한 기능성 다류 개발. 한국식생활문화학회지, 22 : 261-265, 2007.

정석근, 함준상, 김현수, 노영배, 채현석, 안종남, 한기성, 최석호. 유산균의 항알레르기 효과. 한국유가공기술과학회지, 25: 21-25, 2007.

정윤희, 유민정. 더덕 껍질 추출물의 항산화 및 항염증 효과. 아시안뷰티화장품학회지, 16: 347-357, 2018.

지선옥. 상백피 추출물의 항산화 활성 및 미백효과. 한국자원식물학회지, 22: 145-151, 2009.

추수진, 류인자, 김영희, 허광화, 김기호, 한창성, 김수진, 김진웅, 손의동, 유익동. 엉겅퀴 추출물 실리마린의 피부 미백효 과. 대한화장품학회지, 35: 151-158, 2009. 


\section{中文摘要}

\section{用鼠李糖乳杆菌BHN-LAB105发酵的蓟的抗氧化和美白效果评价}

朴Ye-eun ${ }^{1}$, 權奇碩 ${ }^{2}$, 金炳革 $^{1}$, 李仲䅨 ${ }^{*}$

${ }^{1}$ (株)BHNBIO生物产业材料开发研究所, 忠淸北道镇川郡，韩国

2安东大学药学系, 庆尚北道安东市, 韩国

目的: 本研究旨在提高利用鼠李糖乳杆菌BHN-LAB105发酵的蓟（Cirsium japonicum）根, 花和整株植物提取 物的整容功效, 并评估发酵提取物作为化妆品原料的可行性。方法: 样品包括根, 花和整个蓟植物的甲醇提取 物。利用没食子酸和芦丁定量每种提取物的总多酚和类黄酮含量。使用2,2-二苯基-1-苦基肼基（DPPH）自由基 清除测定法确认提取物的抗氧化作用。此外，使用酪氨酸酶抑制法来活性测量每种提取物的增白效果。结果: 与 未发酵的根和全蓟提取物（32\%）相比，发酵根和全蓟提取物的总多酚含量更高（67\%）。在蓟的所有发酵提 取物中总黄酮含量也更高。与未发酵的提取物相比, 发酵的根, 花和整个蓟提取物的DPPH自由基清除活性分 别高出 $67 \% ， 13 \%$ 和 $32 \%$ 。发酵的根，花和整个蓟提取物的酪氨酸酶抑制活性分别高出 $92 \% ， 78 \%$ 和 $65 \%$ 。结 论: 在发酵的全蓟提取物中, 抗氧化和美白效果最高。这表明用鼠李糖乳杆菌BHN-LAB105发酵的全蓟提取物可 以开发为潜在的功能性化妆品原料。

关键词: 蓟，抗氧化，美白效果，发酵，乳酸菌 
